Departamento de Ciência e Tecnologia, Secretaria de Ciências, Tecnologia e Insumos Estratégicos, Ministério da Saúde

Correspondência | Correspondence:

Decit - Departamento de Ciência e Tecnologia

do Ministério da Saúde

Esplanada dos Ministérios

Bloco G sala 845

70058-900 Brasília, DF, Brasil

Texto de difusão técnico-científica do

Ministério de Saúde.

\section{Diretrizes nacionais para biorrepositórios e biobancos de materiais humanos em pesquisa}

\author{
National guidelines for research \\ involving human tissue repositories \\ and biobanks
}

Biobancos são fundamentais para a pesquisa, contribuindo também para as atividades de assistência clínica, pois permitem o armazenamento de amostras biológicas - como sangue, cordão umbilical, tecidos tumorais e normais, entre outras - associadas aos dados clínicos dos pacientes. Um exemplo na pesquisa é o estudo de biomarcadores - características que podem ser mensuradas e que podem indicar processos biológicos e patológicos, possuindo valores de previsão e de prognóstico. Já nas atividades assistenciais, registra-se a importância dos bancos de tumores, que contribuem para o diagnóstico e acompanhamento do estadiamento tumoral.

Em relação à terminologia empregada, existem duas correntes no meio científico: alguns pesquisadores diferenciam biobancos de biorrepositórios enquanto outros consideram esses termos sinônimos.

A Organização Mundial de Saúde define biorrepositório como um prédio, sala ou container onde são armazenados espécimes biológicos, seja para uso clínico ou de pesquisa; e biobanco representa uma coleção organizada de material biológico humano e informações associadas, coletados prospectivamente e armazenados para fins específicos de pesquisa, conforme recomendações e/ou normas técnicas, éticas e operacionais pré-definidas.

Uma preocupação internacional é a constituição de uma rede de biobancos harmonizada, que respeite os preceitos éticos, legais e sociais dos países integrantes, sendo premente, também, a necessidade de elaborar e implantar diretrizes nacionais sobre o tema.

\section{MARCO LEGAL BRASILEIRO}

Atualmente, no Brasil, existe a Lei $n^{\circ} 11105 / 05$ de Biossegurança $^{\mathrm{a}}$ e a RDC 33/06 da Agência Nacional de Vigilância Sanitária (ANVISA) ${ }^{\mathrm{b}}$ que regulamenta o funcionamento dos bancos de células e tecidos germinativos. A Resolução 347/05 do Conselho Nacional de Saúde estabeleceu normas mínimas para o uso e armazenamento de materiais biológicos no âmbito de pesquisa, sendo necessária uma legislação específica sobre a formação de biobancos.

\section{DIRETRIZES NACIONAIS PARA BIOBANCOS}

Para garantir a continuidade da excelência acadêmica no Brasil e a realização de projetos condizentes com os referenciais existentes, é importante estabelecer diretrizes nacionais e garantir a adesão de pesquisadores e instituições de pesquisa. Assim, em 2009, o Departamento de Ciência e Tecnologia do Ministério da Saúde, por meio da Coordenação de Bioética e Ética em Pesquisa da Coordenação-Geral de Fomento à Pesquisa, priorizou ações voltadas para o estabelecimento de padrões técnicos, éticos e legais para a coleta, armazenamento e utilização de material biológico humano para fins científicos.

\footnotetext{
a Brasil. Lei n 11105/05, de 24 de março de 2005. Regulamenta os incisos II, IV e V do § 1o do art. 225 da Constituição Federal, estabelece normas de segurança e mecanismos de fiscalização de atividades que envolvam organismos geneticamente modificados - OGM e seus derivados, cria o Conselho Nacional de Biossegurança - CNBS, reestrutura a Comissão Técnica Nacional de Biossegurança - CTNBio, dispõe sobre a Política Nacional de Biossegurança - PNB, revoga a Lei no 8.974, de 5 de janeiro de 1995, e a Medida Provisória no 2.191-9, de 23 de agosto de 2001, e os arts. 5o, 6o, 7o, 80, 9o, 10 e 16 da Lei no 10.814, de 15 de dezembro de 2003, e dá outras providências. Diario Oficial Uniao. 28 mar 2005 [citado 2009 ago 19];1. Disponível em: http://www.jusbrasil.com.br/legislacao/96812/lei-de-biosseguranca-lei-11105-05

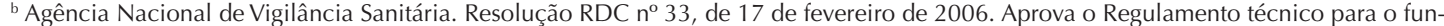
cionamento dos bancos de células e tecidos germinativos. Diario Oficial Uniao. 20 fev 2006[citado 2009 ago 19];Seção 1:38. Disponível em: http://e-legis.anvisa.gov.br/leisref/public/showAct.php?id=20954\&word=

c Conselho Nacional de Saúde. Resolução n 347, de 13 de janeiro de 2005. Regula menta o armazenamento e utilização de material biológico humano no âmbito de projetos de pesquisa. Diario Oficial Uniao. 10 mar 2005[citado 2009 ago 19]; Seção 1:103. Disponível em: http://conselho.saude.gov.br/docs/Reso347.doc
} 
Inicialmente, buscou-se embasamento na literatura e participação nas discussões mundiais sobre o assunto que tinham a preocupação de uma harmonização internacional sobre biobancos.

Em seguida, foram identificadas instituições nacionais que possuíam: biorrepositórios e/ou biobancos de diferentes tipos de material biológico; experiência na operacionalização de biobancos; representatividade regional; e com expertise em bioética com o intuito de mapear os problemas relacionados ao tema e constituir grupo interinstitucional - envolvendo pesquisadores, a
ANVISA e, como observadora, a Comissão Nacional de Ética em Pesquisa (CONEP) - para elaborar Diretrizes Nacionais para biorrepositórios e biobancos de materiais humanos em pesquisa.

Em fase de consolidação, a proposta de diretrizes considera os princípios de responsabilidade social, solidariedade, respeito à pessoa, beneficência, justiça e precaução. O processo, contudo, segue em construção, pois a proposta ainda será levada à consulta pública e, posteriormente, à deliberação nas instâncias colegiadas do Sistema Único de Saúde (SUS). 